\title{
Kejadian Efek Samping Potensial Terapi Obat Anti Diabetes Pasien Diabetes Melitus Berdasarkan Algoritma Naranjo
}

\author{
Raden Joddy Sutama Putra, Anisyah Achmad*, Hananditia Rachma P \\ Jurusan Farmasi, Fakultas Kedokteran, Universitas Brawijaya, Malang, Indonesia
}

\begin{tabular}{l} 
INFO ARTIKEL \\
\hline Sejarah artikel: \\
Penerimaan naskah: 31 \\
Maret 2017 \\
Penerimaan naskah \\
revisi: 19 September \\
2017 Disetujui untuk \\
dipublikasikan 29 \\
September 2017
\end{tabular}

\section{Kata kunci :}

Algoritma Naranjo,

efek samping,

diabetes melitus.

\section{A B S T R A K}

Meningkatnya prevalensi penyakit diabetes melitus di Indonesia menyebabkan peningkatan penggunaan obat anti diabetes yang berpengaruh pada prevalensi kejadian efek samping. Untuk mengkaji efek samping pada penggunaan obat digunakan Algoritma Naranjo, yang merupakan skala resmi di Indonesia untuk mengukur potensi efek samping. Penelitian ini bertujuan untuk mengkaji potensi efek samping terapi obat anti diabetes pada pasien diabetes melitus rawat jalan di Puskesmas Kota Malang. Penelitian ini dinyatakan laik etik dari Fakultas Kedokteran Universitas Brawijaya No. 215/EC/KEPK- S1FARM/03/ 2015. Penelitian ini observasional menggunakan rancangan purposive sampling dengan kriteria inklusi pasien DM telah menggunakan terapi minimal 3 bulan dan menggunakan Algoritma Naranjo sebagai alat bantu pengukuran potensi efek samping. Penelitian ini dilakukan dengan cara wawancara terstruktur dan pengisian kuesioner oleh responden sebanyak 69 responden. Selanjutnya dilakukan penghitungan skor Algoritma Naranjo yang dicocokkan dengan skala potensi efek samping. Hasil penelitian menunjukkan efek samping potensial mual pada penggunaan Metformin 18,53\% (Definite) dan Glimepiride 13,33\% (Definite). Glibenklamid berpotensi menimbulkan efek samping hipoglikemia $15,79 \%$ (Definite). Kesimpulan penelitian adalah penggunaan obat anti diabetes dapat menimbulkan efek samping potensial berdasarkan pengukuran Algoritma Naranjo.

\section{Potential Side Effects of Anti-Diabetic Drug Therapy In Diabetes Mellitus Patients Based On Naranjo Algorithm}

\section{Key words:}

Naranjo algorithm, side effects, diabetes mellitus.

\begin{abstract}
A B S T R A C T
The increasing prevalence of diabetes mellitus in Indonesia led to the increased use of anti-diabetic drugs that affect the prevalence of side effects of anti-diabetic drugs. To assess the side effects on drug use, used Naranjo Algorithm, which is the official scale in Indonesia for the assessment of potential side effects. This study aims to assess the potential side effects of anti-diabetic drug therapy in patients with diabetes mellitus outpatients. Ethical Clearance have accepted from Medical Faculty, University of Brawijaya. This study is an observational study with the sampling method is purposive sampling. The inclusion criteria is DM patients have been using therapy for at least 3 months. This research using Naranjo algorithm as a tool for measuring the potential side effects. It was conducted by interviews and questionnaires with respondents whose were 69 patients. The calculation of the total score and the Naranjo Algorithm matched to the scale of the potential side effects Naranjo. In the research found a potential side effect of the emergence of nausea in Metformin 18,52\% (Definite) and Glimepiride 13, 33 $\%$ (Definite). Glibenclamide potentially adverse effects of hypoglycaemia 15, 79\% (Definite). It can be concluded that the use of anti-diabetic drugs can cause potential side effects is based on the measurement of Naranjo algorithm.
\end{abstract}




\section{Pendahuluan}

Diabetes Melitus (DM) adalah penyakit kronis yang disebabkan oleh ketidakmampuan tubuh untuk memproduksi hormon insulin atau karena penggunaan yang tidak efektif dari produksi insulin. Hal ini ditandai dengan tingginya kadar glukosa darah. Diabetes Melitus terdiri dari dua tipe yaitu tipe pertama DM yang disebabkan keturunan dan penyakit autoimun, serta tipe kedua yang disebabkan gaya hidup. Secara umum, hampir $80 \%$ prevalensi diabetes melitus adalah DM tipe 2 . $^{1}$

Menurut laporan World Health Organization (WHO), Indonesia menempati urutan keempat terbesar dari jumlah penderita diabetes melitus dengan prevalensi $8,6 \%$ dari total penduduk sedangkan posisi urutan di atasnya yaitu India, Cina, dan Amerika Serikat. WHO memprediksi kenaikan jumlah penyandang DM di Indonesia dari 8,4 juta pada tahun 2000 menjadi sekitar 21,3 juta pada tahun 2030. International Diabetes Foundation (IDF) pada tahun 2009 memprediksi kenaikan jumlah penyandang DM dari 7 juta pada tahun 2009 menjadi 12 juta pada tahun 2030. Dari laporan tersebut menunjukkan peningkatan jumlah penyandang DM sebanyak 2-3 kali lipat pada tahun $2030 .^{2}$

Berdasarkan angka pravelensi penderita DM di Indonesia, penggunaan obat anti diabetes mengalami peningkatan yang dapat berpengaruh pada prevalensi terjadinya efek samping. Berdasarkan sebuah penelitian terhadap penggunaan obat anti diabetes, diketahui bahwa efek samping dari obat anti diabetes merupakan masalah serius yang seharusnya dapat ditanggulangi. ${ }^{3}$

Saat ini, penelitian terkait penatalaksanaan pasien DM terfokus pada pengobatan dan perubahan gaya hidup pada pasien, ${ }^{4-6}$ namun sedikit sekali penelitian yang melakukan pengkajian terkait efek samping terkait regimen obat anti diabetes yang diberikan pada pasien. Efek samping yang timbul dari suatu pengobatan dapat menurunkan kualitas hidup pasien, baik dari segi fisik ataupun ekonomi. Prevalensi munculnya efek samping terkait pemberian terapi obat anti diabetes pada pasien diabetes melitus rawat jalan tidak diketahui secara pasti karena masih minimalnya penelitian tentang hal tersebut. Perlu dilakukan pengkajian terhadap potensi efek samping dengan menggunakan metode tertentu.

Pengkajian efek samping penggunaan obat dilakukan di puskesmas Kota Malang karena masih sedikitnya pasien yang mengalami komplikasi penyakit, sehingga efek samping yang timbul pada pengobatan kejadiannya lebih dominan karena obat bukan karena progresivitas penyakit. Algoritma Naranjo merupakan skala yang resmi dipakai di Indonesia untuk pengkajian potensi efek samping. Algoritma ini mengukur potensi efek samping melalui kuesioner dengan skala tertentu yang menunjukkan besar potensi efek samping pada suatu terapi. Algoritma Naranjo dipilih karena dapat menganalisis kejadian efek samping secara kuantitatif dan kualitatif., ${ }^{7,8}$

\section{Metode}

Penelitian dilakukan secara observasional dengan pendekatan cross sectional menggunakan teknik purposive sampling untuk pemilihan sampel pasien dan puskesmas. Penelitian dilaksanakan di Puskesmas Dinoyo, Kedungkandang, dan Kendalsari bulan Maret-Mei 2015. Pemilihan puskesmas berdasarkan keberadaan Apoteker dan perwakilan dari wilayah Kota Malang berdasar area barat, timur, utara dan selatan. Persetujuan etik didapatkan dari Fakultas Kedokteran Universitas Brawijaya No. 215/EC/KEPK- S1- FARM/03/ 2015. Kriteria inklusi untuk puskesmas adalah yang memiliki prevalensi penderita diabetes melitus terbanyak di Kota Malang yang dapat diketahui dari Dinas Kesehatan Kota Malang, sedangkan untuk sampel adalah pasien diabetes melitus rawat jalan yang menerima terapi obat anti diabetes, telah menderita DM minimal tiga bulan yang dibuktikan melalui data rekam medis dan bersedia berpartisipasi dalam penelitian ini dengan pengisian lembar persetujuan. Kriteria eksklusi untuk puskesmas adalah puskesmas di luar Kota Malang dan tidak bersedia untuk dijadikan lokasi pengambilan data, sedangkan untuk pasien adalah pasien DM rawat jalan yang mengalami komplikasi penyakit lain, mengonsumsi obatobatan jangka panjang yang memiliki efek samping sama dengan efek samping obat anti diabetes karena akan berpotensi menyebabkan bias pada skor penilaian.

Instrumen penelitian menggunakan formulir Algoritma Naranjo dan lembar pengumpulan data. Peneliti melakukan wawancara pada pasien untuk menjawab poinpoin pertanyaan pada Algoritma Naranjo. Setiap poin pada tiap pertanyaan akan dijumlahkan dan dilakukan pencocokan dengan Skala Algoritma Naranjo yaitu skor 0 (Doubtful) yang berarti bukan merupakan efek samping, 14 (Possible) mungkin merupakan efek samping, 5-8 (Probable) kemungkinan besar terjadi efek samping dari obat yang dicurigai, dan $\geq 9$ (Definite) pasti terjadi kejadian efek samping. ${ }^{7,8}$

\section{Hasil}

\section{Demografi pasien, obat, dan efek samping}

Sampel sebanyak 69 pasien DM yang memenuhi kriteria inklusi berasal dari tiga puskesmas yang berbeda yaitu Puskesmas Dinoyo sebanyak 26 orang, Puskesmas Kedungkandang sebanyak 29 orang, dan Puskesmas Kendalsari sebanyak 14 orang. Pengambilan data dilakukan di puskesmas untuk 29 pasien dan 40 orang lainnya dengan cara mendatangi kediaman pasien. Data demografi pasien dapat dilihat pada Gambar 1.

Total pasien penderita diabetes melitus yang sesuai kriteria inklusi pada penelitian ini terbesar adalah berjenis kelamin wanita sebayak 47 orang $(68,12 \%)$. Responden yang merupakan pasien DM rawat jalan dengan jumlah usia terbanyak pada kelompok 51-60 tahun yaitu sejumlah 34 orang dengan persentase sebesar 49,28\% (Gambar 2). 


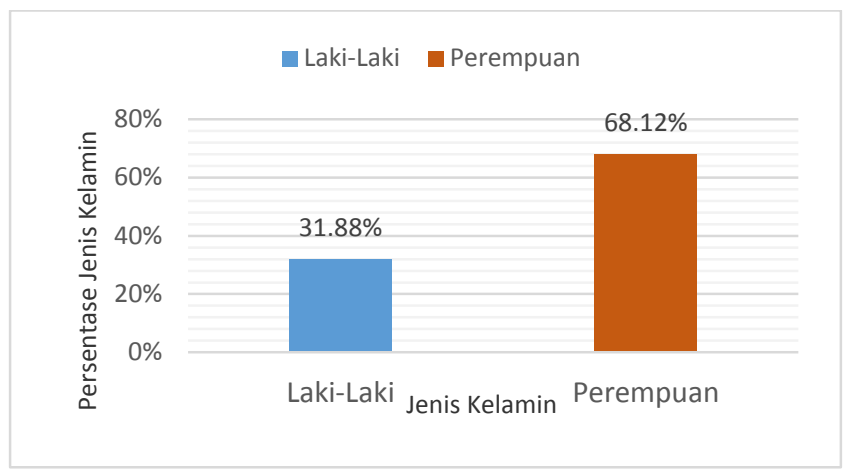

Gambar 1. Persentase Jenis Kelamin Pasien

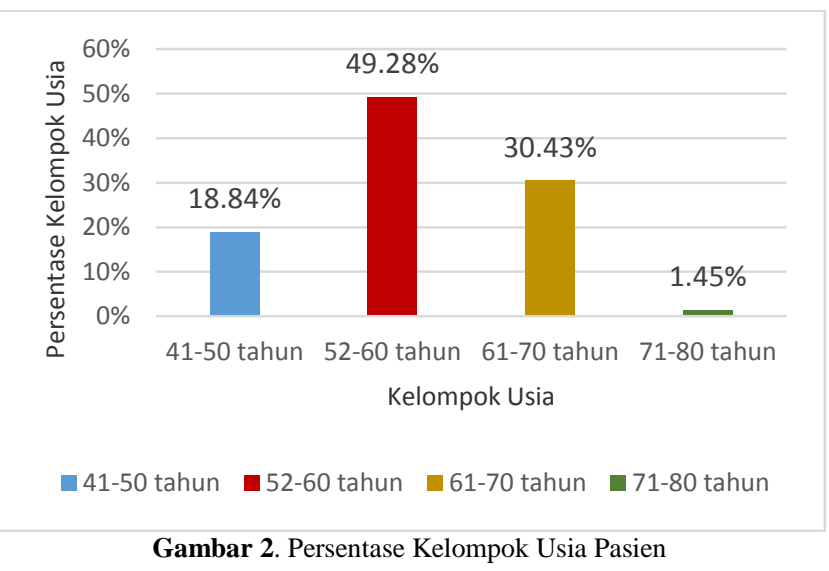

Berdasarkan Gambar 3, jumlah obat anti DM yang paling banyak digunakan adalah metformin yaitu sejumlah 27 pasien dengan persentase $39,13 \%$. Untuk pencatatan temuan kejadian efek samping potensial obat anti DM berupa timbulnya rasa mual, muntah, hipoglikemia, pusing, tremor, dan konstipasi dapat dilihat pada Gambar 4.

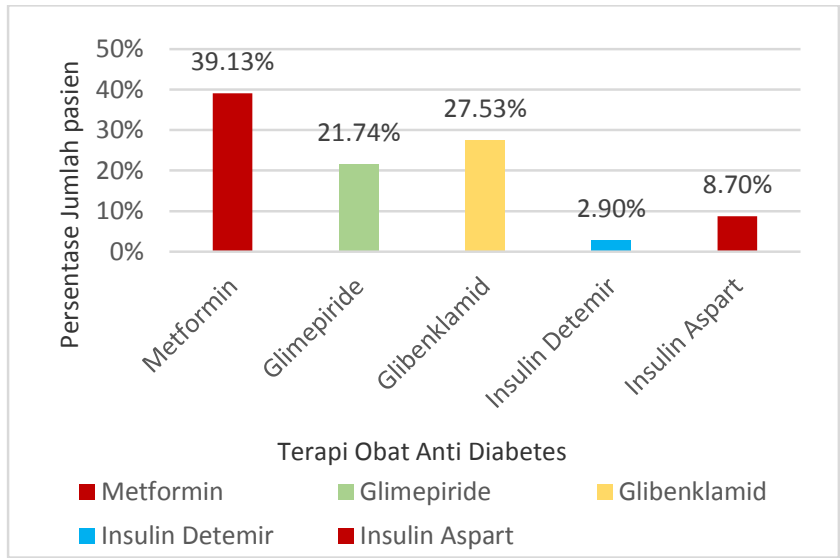

Gambar 3. Persentase Jumlah Pasien Penerima Obat Anti Diabetes

Berdasarkan Gambar 4, ditemukan bahwa efek samping yang sering terjadi adalah timbulnya rasa mual yang terdapat pada beberapa penggunaan obat anti diabetes yang berbeda. Pada penggunaan Metformin, kejadian efek samping yang dominan adalah timbulnya rasa mual yaitu 18,52\%. Pada penggunaan Glibenklamid, kejadian efek samping yang dominan adalah hipoglikemia berdasarkan gejala yang dikeluhkan pasien berupa rasa lemas, pucat, muncul keringat, dan berdebar yaitu 15,79\%. Pada penggunaan Glimepiride, timbul efek samping mual dengan persentase 13,33\%. Pada penggunaan Insulin Aspart dan detemir tidak muncul efek samping (Tabel 1).

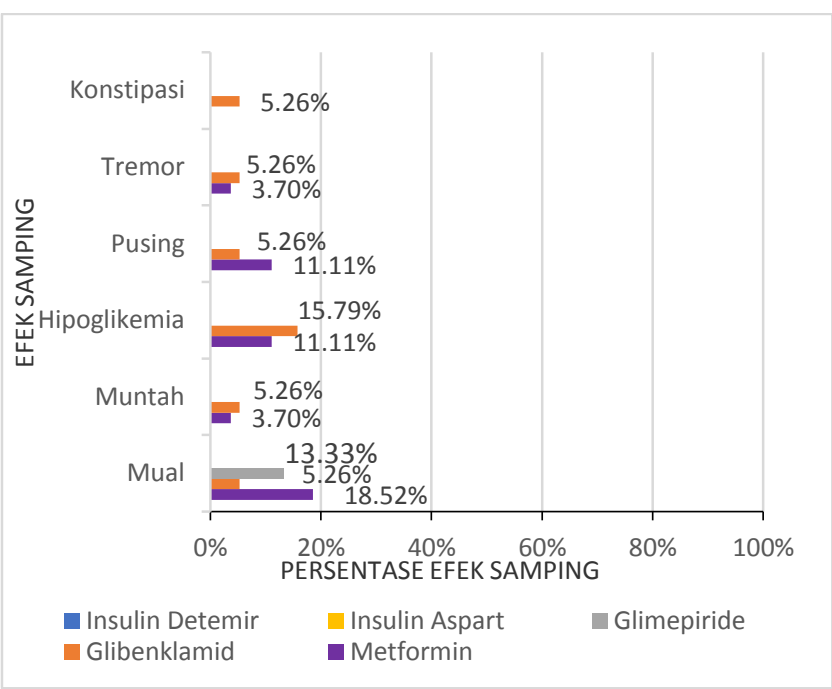

Gambar 4. Persentase Kejadian Efek Samping Obat pada Pemberian Obat Anti Diabetes

Tabel 1. Jumlah Kejadian Efek Samping Obat pada Pemberian Obat

\begin{tabular}{|c|c|c|c|}
\hline \multirow{2}{*}{ No. } & \multicolumn{3}{|c|}{ Antidiabetes } \\
\hline & Nama Obat & $\begin{array}{c}\text { Jumlah } \\
\text { Kejadian Efek } \\
\text { Samping Obat }\end{array}$ & $\begin{array}{c}\text { Persentase } \\
\quad(\%)\end{array}$ \\
\hline \multirow[t]{7}{*}{1.} & Metformin & & \\
\hline & a. Mual & 5 & 18,52 \\
\hline & b. Muntah & 1 & 3,70 \\
\hline & c. Hipoglikemia & 3 & 11,11 \\
\hline & d. Pusing & 3 & 11,11 \\
\hline & e. Tremor & 1 & 3,70 \\
\hline & f. Tanpa efek samping & 14 & 51,85 \\
\hline \multirow[t]{8}{*}{2.} & Glibenklamid & & \\
\hline & a. Mual & 1 & 5,26 \\
\hline & b. Hipoglikemia & 3 & 15,79 \\
\hline & c. Pusing & 1 & 5,26 \\
\hline & d. Tremor & 1 & 5,26 \\
\hline & e. Muntah & 1 & 5,26 \\
\hline & f. Konstipasi & 1 & 5,26 \\
\hline & g. Tanpa efek samping & 11 & 57,89 \\
\hline \multirow[t]{3}{*}{3.} & Glimepirid & & \\
\hline & a. Mual & 2 & 13,33 \\
\hline & b. Tanpa efek samping & 13 & 86,67 \\
\hline 4. & Insulin Aspart & 0 & 0 \\
\hline \multirow[t]{2}{*}{5.} & Insulin Detemir & 0 & 0 \\
\hline & Total & 24 & \\
\hline
\end{tabular}

Hasil pengukuran algoritma naranjo pada pengobatan Berdasarkan Gambar 5, diketahui bahwa efek samping paling potensial dan paling banyak kejadiannya pada penggnaan metformin adalah timbulnya rasa mual (Definite) pada 2 orang pasien yang menggunakan terapi metformin. Efek samping potensial pada penggunaan glibenklamid adalah munculnya hipoglikemia dengan skala tertinggi Definite (Gambar 6), sedangkan penggunaan glimepirid berpotensi menimbulkan efek samping berupa munculnya rasa mual dengan skala tertinggi 
Definite.(Gambar 7).

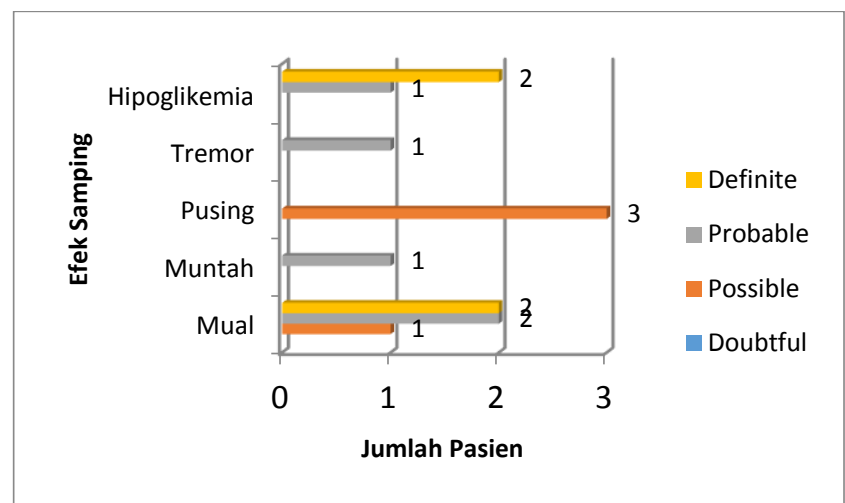

Gambar 5. Penyebaran Skala Naranjo Pada Efek Samping Berdasarkan Penggunaan Metformin

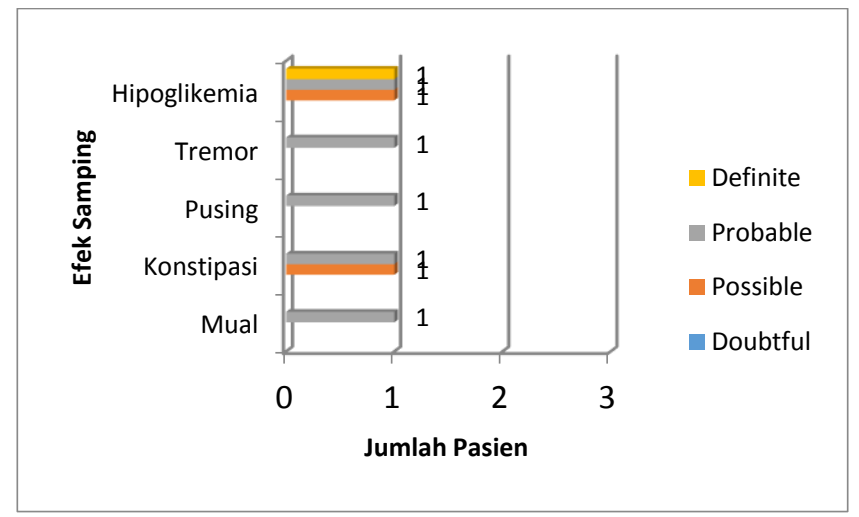

Gambar 6. Penyebaran Skala Naranjo pada Efek Samping Berdasarkan Penggunaan Glibenklamid

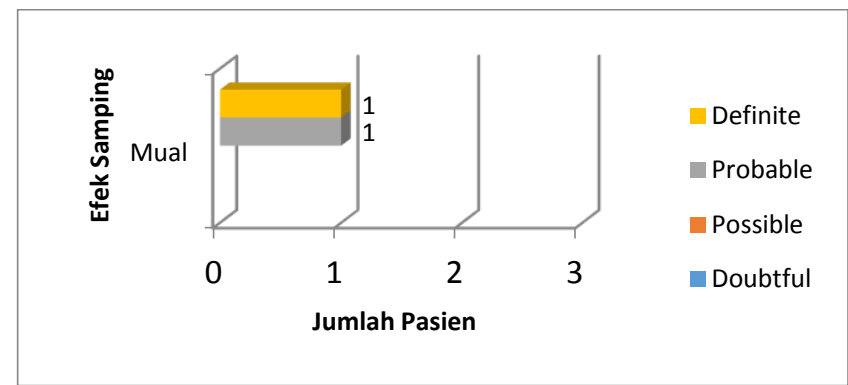

Gambar 7. Grafik Penyebaran Skala Naranjo Pada Efek Samping Berdasarkan Penggunaan Glimepirid

\section{Pembahasan}

Salah Pengkajian efek samping obat anti diabetes pada penelitian ini dilakukan dengan proses wawancara dan menggunakan alat bantu berupa kuesioner Algoritma Naranjo. Pasien akan diwawancarai terkait 10 pertanyaan seputar efek samping akibat penggunaan obat yang terdapat pada Algoritma Naranjo, selanjutnya hasil skor dari tiap pertanyaan akan dijumlahkan dan disesuaikan dengan skala potensi efek samping pada Algoritma Naranjo. Pada skala Naranjo, total skor 0 (nol) menunjukkan doubtful yang menunjukkan bukan merupakan ADR, melainkan karena faktor lain selain dari penggunaan obat yang dicurigai. ${ }^{7}$ Total skor 1-4 menunjukkan possible yang menunjukkan bahwa keluhan pada pasien kemungkinan merupakan kejadian efek samping. Total skor 5-8 menunjukkan probable yang menunjukkan bahwa kemungkinan keluhan pada pasien merupakan kejadian efek samping dari obat yang dicurigai. Total skor lebih dari atau sama dengan 9 menunjukkan definite yang menunjukkan bahwa keluhan pada pasien merupakan efek samping yang diakibatkan oleh penggunaan obat yang dicurigai. Pada pertanyaan ke-6 terkait pemberian plasebo dan ke-7 terkait terdeteksinya konsentrasi toksik obat yang dicurigai, tidak dapat dijawab. Hal ini disebabkan pasien tidak pernah diberikan plasebo dan dilakukan pengecekan terhadap konsentrasi obat dalam darah. Pada pertanyaan ke-10 terkait efek samping obat dengan bukti yang objektif, semua pasien tidak diketahui,kejadian efek sampingnya.. Hal ini dikarenakan tidak ada bukti berupa catatan pada rekam medik yang menunjukkan bahwa pasien mengalami efek samping.

Perbedaan efek samping yang dialami pasien dapat disebabkan oleh beberapa faktor, yaitu usia, obat, adanya penyakit penyerta, dan genetik. Pada pasien geriatrik, kondisi metabolisme tubuh sudah menurun yang disebabkan oleh penurunan fungsi organ $30-40 \%$. Faktor obat yaitu sifat dan potensi obat untuk menimbulkan efek samping seperti pemilihan obat, jangka waktu penggunaan obat, dan adanya interaksi antar obat. Masing-masing obat memiliki mekanisme dan tempat kerja yang berbeda-beda sehingga dapat menimbulkan efek samping yang berbeda. ${ }^{10}$

Pada penelitian ini, ditemukan sebanyak $39,13 \%$ pasien menerima terapi obat anti diabetes golongan biguanid yaitu Metformin dibandingkan dengan pemberian terapi obat anti diabetes lainnya (Glibenklamid, Glimepirid, dan terapi Insulin). Hal ini dikarenakan penggunaan Metformin dapat menurunkan kadar glukosa darah tanpa menyebabkan peningkatan berat badan dan lebih kecil kemungkinan untuk terjadinya hipoglikemia. ${ }^{11}$ Efek penurunan berat badan Metformin melalui penurunan nafsu makan dan mengurangi penyimpanan lemak pada jaringan. ${ }^{13}$

Pada penggunaan Metformin, timbul efek samping obat berupa menimbulkan rasa mual pada empat orang pasien. Total skor Algoritma Naranjo sebesar 3 (tiga) pada salah satu pasien yang menunjukkan bahwa rasa mual kemungkinan merupakan efek samping Metformin yang bersifat possible. Pada dua pasien lain yang mengalami efek samping mual memiliki total skor 7 dan 8 yang dapat diimplementasikan probable yang berarti kemungkinan besar efek samping dari obat yang dicurigai yaitu Metformin. Pada dua pasien lainnya didapati total skor 9 yang dapat diimplementasikan definite yang berarti rasa mual yang dialami pasien ini adalah efek samping Metformin. Efek samping lain dari penggunaan Metformin yaitu muntah, didapati pada satu pasien dengan total skor 7 yang dapat diimplementasikan probable. ${ }^{13}$ Penggunaan Metformin memiliki aksi farmakologi aktivasi reseptor selektif serotonin tipe 3 (5-HT 3) yang menyebabkan gangguan gastrointestinal seperti mual dan muntah. ${ }^{14}$ Selain itu, berdasarkan wawancara dengan pasien, pemberian konseling terkait pencegahan munculnya efek samping tidak 
dilakukan oleh tenaga kesehatan di puskesmas.

Pada reaksi efek samping hipoglikemia yang timbul akibat penggunaan dari Metformin, ditemukan pada tiga pasien dengan total skor Algoritma Naranjo yang berbeda yaitu 5 pada seorang pasien dan 9 untuk dua pasien lainnya. Metformin merupakan obat antidiabetik golongan biguanid yang pada penggunaannya dapat menimbulkan reaksi efek samping metabolik yaitu hipoglikemia. ${ }^{15}$ Mekanisme potensi hipoglikemia diinduksi Metformin termasuk penurunan produksi glukosa hepatik dan penurunan penyerapan glukosa. ${ }^{16}$

Metformin juga dapat menimbulkan rasa pusing yang terjadi pada 3 pasien dengan total skor yang berbeda yaitu seorang pasien dengan skor 4 yang dapat diimplementasikan possible, dan dua pasien lainnya memiliki skor 5 yang dapat diimplementasikan probable. Penggunaan Metformin dapat memicu timbulnya pusing. ${ }^{15}$ Rasa pusing pada penggunaan Metformin merupakan salah satu gejala hipoglikemia. ${ }^{17}$

Tremor pada satu pasien dengan total skor 8 yang dapat dikategorikan probable. Penggunaan Metformin dapat menimbulkan kelainan pada sistem saraf dan menimbulkan tremor. ${ }^{18}$ Metformin dapat menyebabkan terjadinya malabsorpsi vitamin B12 pada ileum sehingga akan menimbulkan gangguan pada sistem saraf dengan munculnya tremor. ${ }^{19}$

Selain Metformin penggunaan obat antidiabetes yang juga menimbulkan efek samping adalah Glibenklamid. Penggunaan obat ini menimbulkan efek hipoglikemia pada tiga orang pasien dengan total skor berbeda yaitu dua pasien memiliki skor 5 dan 7 dapat diimplementasikan probable, sedangkan pada seorang pasien lainnya didapati total skor 9 . Glibenklamid atau Glyburide merupakan obat anti diabetes golongan Sulfonilurea yang memiliki efek samping poten yaitu hipoglikemia. ${ }^{20}$ Hipoglikemia pada penggunaan obat golongan Sulfonilurea (Glibenklamid dan Glimepirid) terjadi karena sesuai dengan mekanisme aksinya yaitu stimulasi sel beta pankreas untuk meningkatkan produksi Insulin yang dapat menurunkan kadar glukosa darah. ${ }^{21}$

Efek samping lain yang muncul pada penggunaan Glibenklamid yaitu konstipasi. Ada dua pasien dengan total skor yang berbeda yaitu 1 dan 5. Pasien yang menggunakan Glibenklamid dapat mengalami konstipasi walau jarang ada laporan mengenai ADR tersebut. ${ }^{22}$

Efek samping tremor juga ditemukan pada seorang pasien pengguna Glibenklamid dengan total skor 8, sedangkan untuk pasien yang mengalami mual terjadi pada seorang pasien dengan total skor 1. Efek samping pusing muncul pada penggunaan Glibenklamid dengan skor 7 . Timbulnya mual, tremor, dan pusing merupakan gejala awal dari hipoglikemia akibat penggunaan obat Sulfonilurea. ${ }^{20}$

Pada penggunaan Glimepirid, ditemukan 2 pasien yang mengalami efek samping berupa mual dengan total skor masing-masing- 8 dan 9. Jumlah skor 8 berarti kemungkinan rasa mual kemungkinan besar adalah efek samping dari penggunaaan Glimepirid dan total skor 9 yang berarti rasa mual yang dialami oleh pasien ini adalah efek samping dari penggunaan Glimepirid. Berdasarkan literatur, penggunaan Glimepirid dapat memicu terjadinya reaksi efek samping berupa rasa mual (nausea) dan muntah (vomiting). ${ }^{24}$ Timbulnya mual, tremor, dan pusing, merupakan gejala awal dari hipoglikemia akibat penggunaan obat golongan Sulfonilurea. ${ }^{21}$

Penggunaan Insulin untuk pasien DM di Puskesmas Kota Malang belum dilakukan. Hal ini merupakan kebijaksanaan puskesmas sebagai fasilitas kesehatan kelas II. Pasien DM yang berkunjung ke puskesmas biasanya belum terkena komplikasi DM dan kualitas hidup masih baik. Sehingga dengan minimalnya komplikasi, penggunaan Insulin juga tidak ada. Apabila ada pasien yang memerlukan Insulin maka akan dirujuk ke rumah sakit.

\section{Ucapan Terima Kasih}

Ucapan terima kasih disampaikan kepada segenap apoteker dan staf di Puskesmas Dinoyo, Puskesmas Kedungkandang, dan Puskesmas Kendalsari yang telah membantu kelancaran pelaksanaan penelitian ini.

\section{Daftar Pustaka}

1. Kementerian Kesehatan Republik Indonesia. Tahun 2030 Prevalensi Diabetes Melitus Di Indonesia Mencapai 21,3 Juta Orang. 2009. (http://www.depkes.go.id/index.php/berita/pressrelease/414-tahun-2030-prevalensidiabetes-melitusdi-indonesia-mencapai-213-juta-orang.html. Diakses 12 Desember 2014).

2. PERKENI. Konsensus Pengelolaan dan Pencegahan Diabetes Melitus Tipe 2 di Indonesia. Jakarta: PERKENI.2011

3. Vickova V, Cornelius V, Kasliwal R, Wilton L, Shakir SA. Hypoglycaemia with oral antidiabetic drugs: results from prescription-event monitoring cohorts of rosiglitazone, pioglitazone, nateglinide and repaglinide. Drug Saf. 2009;32:409-18

4. Istiqomatunnisa. Rasionalitas Penggunaan Obat Anti Diabetes dan Evaluasi Beban Biaya Perbekalan Farmasi pada Pasien Rawat Inap Kartu Jakarta Sehat di Rumah Sakit TNI Angkatan Laut Dr. Mintohardjo. Skripsi. Tidak diterbitkan, Fakultas Kedokteran dan Ilmu Kesehatan, Universitas Islam Negeri, Jakarta. 2014.

5. Khasanah M. Gaya Hidup pada Penderita Diabetes Melitus. Skripsi. Tidak diterbitkan, Fakultas Dakwah Institut Agama Islam Negeri Sunan Ampel, Surabaya. 2012.

6. Widya D. Hubungan Status Gizi dan Aktivitas Fisik Terhadap Diabetes Mellitus pada Lansia di Provinsi Kalimantan Barat. Skripsi. Tidak diterbitkan, Fakultas Ilmu-Ilmu Kesehatan Universitas Esa Unggul, Jakarta. 2015.

7. Naranjo, CA, Busto U., Sellers, E.M., Sandor, P., Ruiz, I., Robert, E.A., et al., A Method For Estimating the 
Probability od Adverse Drug Reactions, Clinical Pharmacology and therapeutics. 1981; 30:2:239-45.

8. BPOM RI. Pedoman Monitoring Efek Samping Obat (MESO) Bagi Tenaga Kesehatan. Jakarta: Badan POM RI. 2012.

9. Alomar MJ. Factors Affecting The Development of Adverse Drug Reactions. Saudi Pharmaceutical Journal. Feb 2013:22:83-94.

10. Arifin AL. Panduan Terapi Diabetes Mellitus Tipe 2 Terkini. Sub Bagian Endokrinologi \& Metabolisme Bagian / UPF. Ilmu Penyakit Dalam. Fakultas Kedokteran. UNPAD / RSUP dr. Hasan Sadikin Bandung. 2011.

11. Malin SK, Kashyap SR. Effects of metformin on weight loss: potential mechanisms. Curr Opin Endocrinol Diabetes Obes. 2014 Oct;21(5):323-9.

12. Drugs.com. Metformin Side Effects. 2015. (http://www.drugs.com/sfx/metformin-sideeffects.html. Diakses 3 Juli 2015).

13. Bouchoucha M, Uzzan B, Cohen R. Metformin and digestive disorders. Diabetes Metab 2011;37:90-6.

14. Stoppler, M.C., Glucophage Side Effects Center. http://www.rxlist.com/glucophage-side-effects-drugcenter.htm. Diakses 1 Agustus 2015.

15. Al Abri SA, S. Hayashi, K.L. Thoren, K.R. Olson. Metformin Ovedose-induced in the absence of other diabetic drugs. June 2013:51(5)(444-447).

16. U.S. National Library of Medicine. Metformin. 2015. (https://www.nlm.nih.gov/medlineplus/druginfo/meds /a696005.html. Diakses 20 Agustus 2015).

17. Cunha, J.P., 2015. Glumetza Side Effects Center. (Online). (http://www.rxlist.com/glumetza-sideeffects-drug-center.htm, Diakses 30 Juni 2015).

18. Ting RZ, Szeto CC, Chan MH, Ma KK, Chow KM. Risk factors of vitamin $\mathrm{B}(12)$ deficiency in patients receiving metformin. Arch Intern Med. 2006; 166(18):1975-9.

19. Drugs.com. Glimepiride Side Effects. 2015. (http://www.drugs.com/sfx/glimepiridesideeffects.html. Diakses 28 Juni 2015).

20. Ogbru, O., Williams, E., Marks, J.W. Insulin: Drug Facts, Side Effects and Dosing. 2015. (http://www.medicinenet.com/insulin/article.htm.

Diakses 23 Juli 2015). 